\title{
Radiation therapy in head and neck cancer
}

\author{
Afnan F. Alfouzan, BDS, MS.
}

\begin{abstract}
تلخص هذه المراجعة بداية العلاج الإشعاعي، وتقنيات العلاج ألخاج

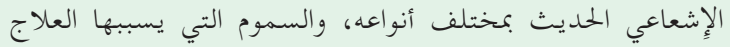

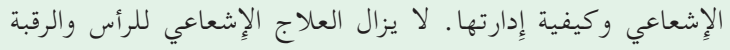

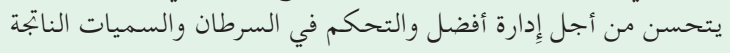

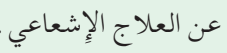

This review summarizes the beginning of radiotherapy, techniques of modern radiation therapy with different types, toxicities induced by radiotherapy and their management. Head and neck radiation therapy is still improving for the better management and control of the cancer and induced radiotherapy toxicities.

Keywords: radiation therapy, head and neck cancer

Saudi Med J 2021; Vol. 42 (3): 247-254

doi: $10.15537 /$ smj.2021.42.3.20210660

From the Department of Prosthodontics, College of Dentistry, King Saud University, Riyadh, Kingdom of Saudi Arabia.

Address correspondence and reprint request to: Dr. Afnan Alfouzan, Department of Prosthodontics, College of Dentistry, King Saud University, Riyadh, Kingdom of Saudi Arabia. E-mail:afnan477@hotmail.com

ORCID ID: http://orcid.org/0000-0003-2535-4641

$\mathrm{H}_{\mathrm{i}}$ ead and neck cancer (HNC) represents one of the top common type with incidence of greater than half a million cases diagnosed annually. Oral, pharyngeal, and laryngeal squamous cell carcinoma (SCC) represent almost $90 \%$ of the cases. Surgical resection, radiotherapy or both have been used over the past few decades. ${ }^{1,2}$ The surveillance, epidemiology and end results data in the United States stated that radiotherapy is generally included in primary oncologic treatments. ${ }^{3}$ Radiotherapy improves clinical, form, and functional outcomes for cancer patients. Currently, almost $75 \%$ of patients with head and neck (SCC) will benefit from radiotherapy, whether primary or adjunct therapy after surgical resection. In the early stages of cancer, radiotherapy can replace the need for surgical resection. ${ }^{4-6}$ Cancer patient can be treated concomitantly with chemoradiotherapy for local advanced cancer or by surgical resection followed by adjuvant radiotherapy. Radiotherapy also used in procedure aims at organ preservation, including avoiding laryngectomy through the use of chemoradiotherapy. ${ }^{7-9}$ The aim of this review was to summarizes development of the radiation therapy for head and neck cancer with different types of induced toxicity and their managements.

Brief description of radiotherapy history. The utilization of ionized radiation in cancer treatment started in the late 19th century. The field of radiology and radiation oncology was born when the x-ray was discovered by Roentgen on November 30, $1895 . .^{10,11}$ After that, in 1896, Grubbe was the first person that therapeutically applied $\mathrm{x}$-rays, was the first person that experienced $\mathrm{x}$-ray dermatitis, was the first to utilize a sheet as a protecting material and was the first person that claimed that radiation could cure cancer patients. ${ }^{10,11} \mathrm{In}$ the same year, Glver Lyon suggested that the radiation might have bactericidal properties. However, in 1902, after several experiments in the field, it was concluded that the radiation had no bactericidal effects, but it was used to assist the resolution of inflammation for bacterial and non-bacterial infections before the introduction of antibiotics, steroids and chemotherapeutic agents. ${ }^{11}$

Marie and Pierre Curies also discovered radium in that century, in 1898. In 1920s, Claudius Regaurd applied the concept of fractionated external beam radiotherapy through multiple weeks and was able to treat multiple cases of HNC. Then, his concept of fractionation was popular internationally. ${ }^{11,12}$

Early radiotherapy was very limited to penetrate deep biological tissues due it its low energy $(100 \mathrm{keV})$. Scientists' efforts were concentrated to increase $\mathrm{x}$-ray energy to reduce dose deposition on the skin and to reach the internal cancer without skin burns. In 1913, William Coolidge produced $\mathrm{x}$-rays with higher energy (200 keV), which was called orthovoltage external beam 
radiotherapy but was still considered low beam energy. Then, several groups after that worked to produce supervoltage $\mathrm{x}$-ray beams. ${ }^{13,14}$

Compact linear accelerators were built on gantries that could rotate around the patient in the 1960s. Additionally, at that time, teletherapy units were introduced, which use cobalt- 60 to produce supervoltage x-ray beams. ${ }^{10}$

Therefore, the conventional type of treatment relied on the 2-dimensional orthogonal skeletal view produced by a fluoroscopic simulator. Two or three radiation beams at different directions at the target results in large volume radiation of the tissue. ${ }^{15}$

Modern radiation technology. Currently, physical examination and multimodality imaging relay on 3-dimensional anatomic details such as computed tomography (CT), magnetic resonance imaging (MRI) and positron emission tomography-computed tomography (PET CT) are important to evaluate the treatment volume and outline of tumor and normal tissues. Multimodality imaging can be combined for more details. For example, CT can combine MRI for better soft tissue details and PET-CT to add functional and metabolic details. 15,16

The high dose volume will include the primary site of the cancer with the lymph node regions, which are considered the areas of gross disease or gross tumor volume (GTV). Gross tumor volume extends to involve the spread of the cancer to involve the microscopic cancer involvement, which is the clinical tumor volume (CTV1), which is enlarged by 2.5 to $10 \mathrm{~mm}$ to the planning target volume (PTV1) depending on the microscopic evaluation of the surgical specimens, which is the typical treatment dose that is usually 66 to 74 Gy (Gray) in 2 Gy fractions or 81.6 Gy in 1.2 Gy fractions. ${ }^{17}$

Therefore, multiple radiation beams will be directed towards the tumor from different angles and planes. Each beam is designed to follow the outline of the target with the aim to converge in order to deliver the planned dose with only fractions of radiation to the normal surrounding tissues. Therefore, the process of tumor wrapping with high radiation dose with minimum dose delivered to the normal adjacent tissues is called conformal radiation therapy. ${ }^{15}$

Disclosure. Authors have no conflict of interests, and the work was not supported or funded by any drug company.
Numerous advanced radiotherapy techniques had been used to reduce the radiation induced toxicities such as intensity modulated radiation therapy (IMRT), which is an advent form of 3-dimensional conformal radiation therapy (3D CRT) with the ability to change the intensity of radiation across each beam, whereas $3 \mathrm{D}$ CRT delivers radiation to the target with a minimum dose to the adjacent tissues. ${ }^{18,19}$

Over the past 20 years, IMRT became a common technique for $\mathrm{HNC}$ patients due to its ability to selectively target the primary site and lymph node regions at risk by decreasing the dose to the healthy adjacent tissues, thus improving therapeutic index by decreasing the acute and chronic morbidity, improving target volume coverage with locoregional control. ${ }^{20-25}$

Intensity modulated radiation therapy permits improved dose confirmation over irregular-shaped cancer with better sparing of adjacent normal structures. ${ }^{26}$ It is employed usually for the nasopharynx and oropharynx, avoiding important structures such as brain, brain stem, optic, optic stem and parotid salivary gland. ${ }^{19,27,28}$ Lamberchet et $\mathrm{al}^{29}$ reported significantly less xerostomia related to IMRT when compared to 3D CRT after 6 months of treatment (82\% versus 91\%). Additionally, Rathod et $\mathrm{al}^{30}$ compared the quality of life outcomes for head and neck SCC treated with 2 different radiation therapies, IMRT and 3D CRT, and they found significantly better dry mouth, mouth opening, sticky saliva, pain, senses, swallowing, feeling ill and insomnia on the symptoms scale.

Volumetric modulated arc radiotherapy is the advanced form of IMRT, which delivers an exactly shaped 3D dose distribution with a 360-degree rotation of the gantry in a single or multi-arc treatment. Therefore, the radiotherapy machine can spin over the patient body during the course of treatment. The machine constantly reshapes and changes the intensity of the radiation beam as it rotates around the patient. ${ }^{31,32}$

Fractionation of radiotherapy. Fractionation of radiotherapy is defined as radiation dose over time that is considered one of the essential factors that controls the outcome of radiotherapy. ${ }^{33}$ For standard radiotherapy, it is generally given in 2 Gray (Gy) fractions per day, 5 days per week for a total of 60 to $70 \mathrm{~Gy} .{ }^{34}$ In order to improve local control and reduce the toxicity effect, it can be divided in 2 approaches of fractionation: hyperfractionation and accelerated fractionation. Hyperfractionation represents small doses of radiation given to the patient 2 or 3 times per day, usually 1.10-1.25 Gy, aiming to reduce the toxicity effect on the normal cells, whereas accelerated fractionation aims to reduce cancer repopulation 
between the sessions by reducing the total treatment time and adding more fractions per week (10 Gy per week), resulting in improved locoregional control.,35-37 Bourhis et $\mathrm{al}^{38}$ reviewed 15 trials in their meta-analysis study that compared conventional radiotherapy with hyperfractioned and accelerated radiotherapy for SCC patients and concluded that the patients who received altered fractionated radiotherapy had better tumor control and survival compared to conventional therapy. Additionally, $\mathrm{Fu}$ et $\mathrm{al}^{33}$ found that the hyper fractionation and accelerated fractionation were more efficient than conventional fractionation for locally advanced cancer. Hypofractionation of radiotherapy also has been used as palliative treatment for advanced $\mathrm{HNC}$, where a small amount of fractionation is given with higher radiation doses over a shorter period of time compared with the other regimens. ${ }^{39}$

Treatment delivery verification. Image-guided radiotherapy is important before radiation delivery, especially with IMRT, where any changes in the patient's position can affect the radiotherapy field. Therefore, through the use of an immobilization custom fitted thermoplastic mask to position the patient in the field of radiation to limit the motion of his shoulder, jaw and head, images can be taken by cone beam CT, for example, to assess the bony landmarks and compare it with the initial planning scan. The patient can be positioned in the planned radiation field as long as it is the same position for each treatment dose. ${ }^{40}$

Adaptive radiotherapy. It is usually common that the tumor and the adjacent normal tissues change after a period of radiotherapy. Three percent volume shrinkage of the tumor and lymph nodes occurs daily, with changing in the tumor size, form and location during the course of the treatment. ${ }^{41}$ Weight and muscle mass loss also leads to changes in the patient outcomes. ${ }^{42}$ The parotid gland, for example, changes its position medially into a higher radiation field. ${ }^{43}$ Thus, re-planning of the radiation dose to compensate for changes in anatomy and target volume, which is called adaptive radiotherapy, results in superior quality of life and efficacy of treatment compared to not replanning. ${ }^{44-46}$

Proton radiotherapy. Proton beam therapy was introduced in radiotherapy to be used when the cancer is close to critical anatomical structures because the beam energy can be aimed at an exact depth, with consequent dose decrease. Therefore, it is different than external photon (x-ray) radiotherapy in which it can keep the same radiation dose for the normal adjacent tissues when the radiation dose is escalating to the tumor area. Additionally, it can deliver a reduced dose to the surrounding structure with the same radiation dose delivered to the tumor. ${ }^{47-49}$

Cellular and cancer response to radiation. When high-voltage $\mathrm{x}$-ray penetrates the tissues, it ionizes the oxygen and produces free oxygen radicals and cancer death. ${ }^{50}$ Therefore, this high-voltage $\mathrm{x}$-ray can damage the genetic material of the cells (DNA), which blocks division and proliferation.

The presence of oxygen increases the response to radiotherapy. Cancer cells are usually hypoxic and relatively resist radiation therapy. The use of radiation sensitizers may improve the response to radiation. ${ }^{35}$

The chemotherapeutic agent cisplatin (cisdiaminedichloroplatinum, CDDP) can act as a radiosensitizer. Cisplatin is commonly used with concurrent radiotherapy for locoregional control and laryngeal preservation. ${ }^{51}$ Bonner et $\mathrm{al}^{52}$ reported a significantly better 5 years overall survival for patients with locoregional advanced SCC of head and neck with chemoradiotherapy compared with radiation alone.

Radiation toxicity. In addition to the anti-tumor effect of radiotherapy, it can cause injury to the normal tissues positioned in the area of radiation. Toxicity after radiotherapy is defined as adverse events or complications that occur after radiation, which can be any changes in the normal tissues with temporary or permanent nature. It can be considered as acute toxicity when it occurs within 90 days of treatment or late toxicity when it happens after 90 days of radiation ${ }^{53-55}$ (Figure 1). Toxicity is found to be more severe when radiotherapy is combined with chemotherapy. Cooper et $\mathrm{a}^{56}$ reported that the incidence of acute toxicity of grade 3 or more was $77 \%$ in patients who received chemoradiotherapy while only $34 \%$ in patients who received radiotherapy alone.

Post-radiation complications vary from skin rashes to osteoradionecrosis. The common acute toxicities include mucositis, dermatitis, dysphagia and odynophagia, hoarseness and loss of taste caused by laryngeal edema, whereas the late toxicities include osteoradionecrosis, xerostomia, subcutaneous fibrosis, thyroid dysfunction, trismus, sensorineural hearing loss, myelitis, and pharyngeal or oropharyngeal stenosis..$^{57,58}$ Usually, tissues with rapid turnover rates show acute reactions, whereas tissue with slower turnover has late reactions that may take months or years. ${ }^{58}$

Mucositis, which is defined as inflammation of the oral and oropharyngeal mucosa, is one of the first acute toxicities that affect the patient. It appears within the first 2-3 weeks of treatment as erythema of the oral mucosa that proceeds to ulceration and pseudomembranes, and it usually affects the non-keratinized oral mucosa more 


\section{Radiation toxicity}

\section{Acute toxicity}

-Mucositis

-Dermatitis

-Dysphagia

- Odynophagia

- Loss of taste

-HoarsenessF

\section{Chronic toxicity}

-Osteoradionecrosis

-Xerostomia

- Subcutaneous fibrosis

- Trismus

- Thyroid dysfunction

- Sensorineural hearing loss

- Pharyngeal or oropharyngeal stenosis

Figure 1 - Examples of head and neck radiation toxicity.

than the keratinized ones. ${ }^{59,60}$

Mucositis may result in local discomfort with difficulty in eating and drinking that may cause nutritional problems to the patient leading to weight loss that may necessitate the use of a gastrostomy tube, whereas with severe mucositis, radiotherapy needs to stop and the patient may need hospital admission, which prolongs the time of treatment. ${ }^{53,61-63}$ During radiation therapy, some mouthwashes can be prescribed to the patient to help relieve some of the oropharyngeal symptoms. For example, Akabutu's mouthwash that is produced by Dr. John Akabutu while he works at the University of Alberta Hospital and the Cross Cancer Institute, contains viscous lidocaine, nystatin suspension, hydrocortisone, glycerin and normal saline. ${ }^{64}$ However, the epithelial surface usually healed in 20-40 days after the completion of the radiotherapy depending on the severity of the lesion. ${ }^{65}$

Over $90 \%$ of HNC patients who received radiotherapy suffer from xerostomia, oral discomfort, difficulty in mastication, speech and swallowing, loss of taste and worsening of periodontal hygiene..$^{54,62,66}$
Additionally, over $50 \%$ of them produce dental caries and oral mucositis with an increased risk of trismus, skin fibrosis, fungal infection, periodontitis, odynophagia and osteoradionecrosis. ${ }^{67}$ To help prevent xerostomia, numerous strategies have been used, such as surgical transfer of salivary glands, a radiotherapy method that spares the salivary glands, a radioprotectant such as amifostine, and intraglandular botulinum therapy. ${ }^{68}$ In 2001, Seikaly et $\mathrm{a}^{69}$ introduced a novel technique of transferring the submandibular salivary gland surgically to the submental space before the radiotherapy. During radiotherapy, usually, the submental region shielded and received scattered radiation, which is considered just $5 \%$ of the total radiation dose. ${ }^{70}$ The submandibular salivary gland can produce 200 to $300 \mathrm{~mL}$ of saliva per day, so by Seikaly et al ${ }^{69}$ and Jha's ${ }^{70}$ method of submandibular salivary gland transfer, it can preserve the gland function after radiation treatment with the proper shielding. ${ }^{71}$ This method can be applied for patients with primary tumors of the oropharynx, hypopharynx, larynx and skin as they do not have lymphatic involvement of level I nodes. ${ }^{69}$ Sood et $\mathrm{al}^{72}$ in 2014 reviewed studies of 12 institutes that used Seikaly et $\mathrm{al}^{69}$ and Jha's ${ }^{70}$ methods to prevent radiation induced xerostomia, and they found that in 177 patients, salivary gland transfer prevented xerostomia in $82 \%$ of them. Additionally, after approximately a year of radiotherapy, the stimulated salivary flow returned to $88 \%$ and un-stimulated to $76 \%$ of presurgical value. A strict high-fluoride regimen should be followed after radiation therapy to help prevent dental caries, especially with a hyposalivation environment. ${ }^{73,74}$ Attempts can be carried out to restore the salivary flow of patients through the use of muscarinic cholinergic agonists to stimulate salivary flow. Saliva replacement can be used if stimulation fails. Sialagogues, such as salivary replacement rinses, carmellose and mucin sprays, polyacrylic acid, carboxymethylcellulose, and sugarless gum, can improve symptoms. ${ }^{68,75-78}$

Limited mouth opening (trismus) can also occur if the temporomandibular joint or masticatory muscles or both were included in the area of radiation, which results in muscle fibrosis and scarring with fibrosis of the ligaments around the joint, which may interfere with patient's nutrition, speech and dental care. ${ }^{79,80}$ Less than $35 \mathrm{~mm}$ is considered as the functional cut-off point of trismus. ${ }^{81}$ It is considered as a late toxicity event that happens after radiotherapy and can be a life-long problem. Some therapeutic interventions seem to improve trismus such as pentoxifylline, botulinum toxin and through exercises with the Therabite Jaw Motion Rehabilitation device. ${ }^{82,83}$ 
Osteoradionecrosis is a serious and late toxicity event that occurs after radiation therapy when the irradiated tissue breaks down and fails to repair after the injury, so the irradiated bone is exposed and undergoes necrosis. The risk increases with a radiation dose above $60 \mathrm{~Gy}$, with the prevalence rate between $5 \%$ and $15 \%$ in the patients who received radiotherapy, which occurred between 22 and 47 months after radiation. In the head and neck region, usually, the mandibular bone is more susceptible to osteoradionecrosis. ${ }^{53,73,84-86}$

The risk of osteoradionecrosis increases after oral surgery procedures after radiotherapy, which emphasizes the need for pre-radiation dental management to reduce the need for teeth extraction after radiotherapy. ${ }^{73}$ Prophylaxis extraction of the teeth with unfavorable conditions within the area of planned irradiation was recommended. ${ }^{87}$ Several studies suggested a minimum of 2 weeks waiting time between teeth extraction and initiation of radiotherapy. ${ }^{84,88}$

Osteoradionecrosis induces fibrosis and thrombosis, bone marrow damage, necrosis of lacunar osteocytes, and loss of bone and soft tissue healing. ${ }^{89,90}$ Its treatment usually includes surgical resection and vascular graft reconstruction when it involves pathological fractures or threatening of fractures. Hyperbaric oxygen therapy may help prevent the incidence of osteoradionecrosis before any surgical procedure to the irradiated area. ${ }^{53}$

Hyperbaric oxygen therapy (HBO). Hyperbaric oxygen therapy is utilized for patients who suffer from severe carbon monoxide poisoning, arterial embolism, and decompression sickness. Additionally, it can be used to limit chronic radiation injuries. ${ }^{78,86,91}$

One hundred percent oxygen can be delivered to the patients in a hyperbaric chamber according to specific protocols. Hyperbaric oxygen therapy dose can be delivered over several days before and after the surgical procedure for irradiated patients. The standard Marx $30 / 10 \mathrm{HBO}$ protocol is used, where 30 times of $\mathrm{HBO}$ treatment are delivered to the patient at 2.4 atmosphere for 90 minutes before surgical procedure, followed by 10 times of $\mathrm{HBO}$ treatment after the surgical procedure with the same time and atmosphere setting. ${ }^{78,92}$

Taher et $\mathrm{al}^{91}$ in 2015 assessed the efficacy of (HBO) in the management of chronic radiation-induced tissue injuries. They found a high response rate in osteoradionecrosis prophylaxis because of radiation induced dental disease. Additionally, they noticed improvement in necrosis of the head and neck tissues, mandibular osteoradionecrosis and xerostomia. In 2012, Hampson et $\mathrm{al}^{93}$ evaluated the outcomes of 411 patients over 8 years that showed complete healing after teeth extraction; the used of $\mathrm{HBO}$ protocol was 20/10 for 166 patients and 30/10 for 43 patients before and after the extraction. Hyperbaric oxygen therapy could also be used as an adjuvant treatment to the surgical treatment for osteoradionecrosis to fasten the healing of the osseous and soft tissues. ${ }^{94}$

The patients demonstrate some complications after $\mathrm{HBO}$, which are related to increased oxygen and pressure levels. Barotrauma of the middle ear, sinus, lung and teeth may occur, which result from failure to balance pressure between the atmosphere and the air-filled space in the patient body resulting in a "squeeze." Increased oxygen levels may result in transient myopic change and pulmonary oxygen toxicity, which resolve after several days. Additionally, with patients, lower seizure thresholds may suffer from generalized tonic-clonic seizure in rare conditions. ${ }^{78}$

In conclusion, over the past decade, improvements in head and neck management through radiotherapy have been added. Modern radiotherapy techniques resulted in the improvement of cancer control. Several types of management of toxicity-induced radiotherapy were implemented to improve the patients' quality of life. The field of radiotherapy is still growing to control tumors and improve radiation-induced toxicity.

Acknowledgment. The author acknowledges the American Journal Experts company for the professional editing of the manuscript.

\section{References}

1. Vigneswaran N, Williams MD. Epidemiologic trends in head and neck cancer and aids in diagnosis. Oral Maxillofac Surg Clin North Am 2014; 26: 123-141.

2. Chi AC, Day TA, Neville BW. Oral cavity and oropharyngeal squamous cell carcinoma--an update. CA Cancer J Clin 2015; 65: 401-421.

3. Virnig BA, Warren JL, Cooper GS, Klabunde CN, Schussler N, Freeman J. Studying radiation therapy using SEER-Medicarelinked data. Medical Care 2002; 40: IV-49.

4. Barton MB, Jacob S, Shafiq J, Wong K, Thompson SR, Hanna TP, Delaney GP. Estimating the demand for radiotherapy from the evidence: a review of changes from 2003 to 2012. Radiother Oncol 2014; 112: 140-144.

5. Saloura V, Langerman A, Rudra S, Chin R, Cohen EE. Multidisciplinary care of the patient with head and neck cancer. Surg Oncol Clin N Am 2013; 22: 179-215.

6. van der Molen L, van Rossum MA, Burkhead LM, Smeele LE, Hilgers FJ. Functional outcomes and rehabilitation strategies in patients treated with chemoradiotherapy for advanced head and neck cancer: a systematic review. Eur Arch Otorhinolaryngol 2009; 266: 889-900.

7. Forastiere AA, Goepfert H, Maor M, Pajak TF, Weber R, Morrison W, Glisson B, Trotti A, Ridge JA, Chao C, Peters G, Lee DJ, Leaf A, Ensley J, Cooper J. Concurrent chemotherapy and radiotherapy for organ preservation in advanced laryngeal cancer. N Engl J Med 2003; 349: 2091-2098. 
8. Wolf GT, Hong K, Fisher S. The Department of Veterans Affairs Laryngeal Cancer Study Group: Induction chemotherapy plus radiation compared with surgery plus radiation in patients with advanced laryngeal cancer. N Engl J Med 1991; 324: 1685-1690.

9. Marur S, Forastiere AA. Head and neck squamous cell carcinoma: Update on epidemiology, diagnosis, and treatment. Mayo Clin Proc 2016; 91: 386-396.

10. Connell PP, Hellman S. Advances in radiotherapy and implications for the next century: a historical perspective. Cancer Res 2009; 69: 383-392.

11. Lederman M. The early history of radiotherapy: 1895-1939. Int J Radiat Oncol Biol Phys 1981; 7: 639-648.

12. Kaplan HS. Historic milestones in radiobiology and radiation therapy. Semin Oncol 1979; 6: 479-489.

13. Case JT. Some early experiences in therapeutic radiology; formation of the American Radium Society. Am J Roentgenol Radium Ther Nucl Med 1953; 70: 487-491.

14. Coolidge WD. Hot-cathode device. [cited 1928]. Available from: https://patents.google.com/patent/US1684263A/en

15. Mallick I, Waldron JN. Radiation therapy for head and neck cancers. Semin Oncol Nurs 2009; 25: 193-202.

16. Grégoire V, Langendijk JA, Nuyts S. Advances in Radiotherapy for Head and Neck Cancer. J Clin Oncol 2015; 33: 3277-3284.

17. Pfister DG, Ang KK, Brizel DM, Burtness BA, Cmelak AJ, Colevas AD, et al. Head and neck cancers. J Natl Compr Canc Netw 2011; 9: 596-650.

18. Duprez F, Madani I, Bonte K, Boterberg T, Vakaet L, Derie $\mathrm{C}$, et al. Intensity-modulated radiotherapy for recurrent and second primary head and neck cancer in previously irradiated territory. Radiother Oncol 2009; 93: 563-569.

19. Kam MK, Leung SF, Zee B, Chau RM, Suen JJ, Mo F, et al. Prospective randomized study of intensity-modulated radiotherapy on salivary gland function in early-stage nasopharyngeal carcinoma patients. J Clin Oncol 2007; 25: 4873-4879.

20. Lee N, Harris J, Garden AS, Straube W, Glisson B, Xia P, et al. Intensity-modulated radiation therapy with or without chemotherapy for nasopharyngeal carcinoma: radiation therapy oncology group phase II trial 0225. J Clin Oncol 2009; 27: 3684-3690.

21. Lee NY, de Arruda FF, Puri DR, Wolden SL, Narayana A, Mechalakos J, et al. A comparison of intensity-modulated radiation therapy and concomitant boost radiotherapy in the setting of concurrent chemotherapy for locally advanced oropharyngeal carcinoma. Int J Radiat Oncol Biol Phys 2006; 66: 966-974.

22. Fregnani ER, Parahyba CJ, Morais-Faria K, Fonseca FP, Ramos PA, de Moraes FY, et al. IMRT delivers lower radiation doses to dental structures than 3DRT in head and neck cancer patients. Radiat Oncol 2016; 11: 116.

23. Lee N, Xia P, Quivey JM, Sultanem K, Poon I, Akazawa C, et al. Intensity-modulated radiotherapy in the treatment of nasopharyngeal carcinoma: an update of the UCSF experience. Int J Radiat Oncol Biol Phys 2002; 53: 12-22.

24. Kam MK, Teo PM, Chau RM, Cheung KY, Choi PH, Kwan $\mathrm{WH}$, et al. Treatment of nasopharyngeal carcinoma with intensity-modulated radiotherapy: the Hong Kong experience. Int J Radiat Oncol Biol Phys 2004; 60: 1440-1450.
25. Gupta T, Agarwal J, Jain S, Phurailatpam R, Kannan S, GhoshLaskar S, et al. Three-dimensional conformal radiotherapy (3D-CRT) versus intensity modulated radiation therapy (IMRT) in squamous cell carcinoma of the head and neck: a randomized controlled trial. Radiother Oncol 2012; 104: 343-348.

26. Lee NY, Le QT. New developments in radiation therapy for head and neck cancer: intensity-modulated radiation therapy and hypoxia targeting. Semin Oncol 2008; 35: 236-250.

27. Kwong DL, Pow EH, Sham JS, McMillan AS, Leung LH, Leung WK, et al. Intensity-modulated radiotherapy for early-stage nasopharyngeal carcinoma: a prospective study on disease control and preservation of salivary function. Cancer 2004; 101: 1584-1593.

28. de Arruda FF, Puri DR, Zhung J, Narayana A, Wolden S, Hunt $M$, et al. Intensity-modulated radiation therapy for the treatment of oropharyngeal carcinoma: the Memorial SloanKettering Cancer Center experience. Int J Radiat Oncol Biol Phys 2006; 64: 363-373.

29. Lambrecht M, Nevens D, Nuyts S. Intensity-modulated radiotherapy vs. parotid-sparing $3 \mathrm{D}$ conformal radiotherapy. Effect on outcome and toxicity in locally advanced head and neck cancer. Strablenther Onkol 2013; 189: 223-229.

30. Rathod S, Gupta T, Ghosh-Laskar S, Murthy V, Budrukkar A, Agarwal J. Quality-of-life (QOL) outcomes in patients with head and neck squamous cell carcinoma (HNSCC) treated with intensity-modulated radiation therapy (IMRT) compared to three-dimensional conformal radiotherapy (3D-CRT): evidence from a prospective randomized study. Oral Oncol 2013; 49: 634-642.

31. Otto K. Volumetric modulated arc therapy: IMRT in a single gantry arc. Med Phys 2008; 35: 310-317.

32. Vanetti E, Clivio A, Nicolini G, Fogliata A, Ghosh-Laskar S, Agarwal JP, et al. Volumetric modulated arc radiotherapy for carcinomas of the oro-pharynx, hypo-pharynx and larynx: a treatment planning comparison with fixed field IMRT. Radiother Oncol 2009; 92: 111-117.

33. Fu KK, Pajak TF, Trotti A, Jones CU, Spencer SA, Phillips TL, et al. A Radiation Therapy Oncology Group (RTOG) phase III randomized study to compare hyperfractionation and two variants of accelerated fractionation to standard fractionation radiotherapy for head and neck squamous cell carcinomas: first report of RTOG 9003. Int J Radiat Oncol Biol Phys 2000; 48: 7-16.

34. Pignon JP, Bourhis J, Domenge CO, Designé LL, Mach-NC Collaborative Group. Chemotherapy added to locoregional treatment for head and neck squamous-cell carcinoma: three meta-analyses of updated individual data. The Lancet 2000; 355: 949-955.

35. Forastiere A, Koch W, Trotti A, Sidransky D. Head and neck cancer. N Engl J Med 2001; 345: 1890-1900.

36. Overgaard J, Hansen HS, Specht L, Overgaard M, Grau C, Andersen E, et al. Five compared with six fractions per week of conventional radiotherapy of squamous-cell carcinoma of head and neck: DAHANCA 6\&7 randomised controlled trial. The Lancet 2003; 362: 933-940.

37. Nguyen LN, Ang KK. Radiotherapy for cancer of the head and neck: altered fractionation regimens. The Lancet Oncology 2002; 3: 693-701.

38. Bourhis J, Overgaard J, Audry H, Ang KK, Saunders M, Bernier J, et al. Hyperfractionated or accelerated radiotherapy in head and neck cancer: a meta-analysis. The Lancet 2006; 368: 843-854. 
39. Park HJ, Griffin RJ, Hui S, Levitt SH, Song CW. Radiationinduced vascular damage in tumors: implications of vascular damage in ablative hypofractionated radiotherapy (SBRT and SRS). Radiat Res 2012; 177: 311-327.

40. Parvathaneni U, Laramore GE, Liao JJ. Technical advances and pitfalls in head and neck radiotherapy. J Oncol 2012; 2012: 597467.

41. Castadot P, Geets X, Lee JA, Christian N, Grégoire V. Assessment by a deformable registration method of the volumetric and positional changes of target volumes and organs at risk in pharyngo-laryngeal tumors treated with concomitant chemo-radiation. Radiother Oncol 2010; 95: 209-217.

42. Geets X, Tomsej M, Lee JA, Duprez T, Coche E, Cosnard G, et al. Adaptive biological image-guided IMRT with anatomic and functional imaging in pharyngo-laryngeal tumors: impact on target volume delineation and dose distribution using helical tomotherapy. Radiother Oncol 2007; 85: 105-115.

43. Barker Jr JL, Garden AS, Ang KK, O’Daniel JC, Wang H, Court LE, et al. Quantification of volumetric and geometric changes occurring during fractionated radiotherapy for headand-neck cancer using an integrated CT/linear accelerator system. Int J Radiat Oncol Biol Phys 2004; 59: 960-970.

44. Mendenhall WM, Amdur RJ, Palta JR. Intensity-modulated radiotherapy in the standard management of head and neck cancer: promises and pitfalls. J Clin Oncol 2006; 24: 2618-2623.

45. Schwartz DL, Garden AS, Thomas J, Chen Y, Zhang Y, Lewin J, Chambers MS, Dong L. Adaptive radiotherapy for headand-neck cancer: initial clinical outcomes from a prospective trial. Int J Radiat Oncol Biol Phys 2012; 83: 986-993.

46. Yang H, Hu W, Wang W, Chen P, Ding W, Luo W. Replanning during intensity modulated radiation therapy improved quality of life in patients with nasopharyngeal carcinoma. Int J Radiat Oncol Biol Phys 2013; 85: e47-e54.

47. Holliday EB, Frank SJ. Proton radiation therapy for head and neck cancer: a review of the clinical experience to date. Int J Radiat Oncol Biol Phys 2014; 89: 292-302.

48. Suit H, Urie M. Proton beams in radiation therapy. J Natl Cancer Inst 1992; 84: 155-164.

49. Mendenhall NP, Malyapa RS, Su Z, Yeung D, Mendenhall WM, Li Z. Proton therapy for head and neck cancer: rationale, potential indications, practical considerations, and current clinical evidence. Acta Oncol 2011; 50: 763-771.

50. Lester SY, Yang WY. Principles and management of head and neck cancer. Head and Neck 2012; 30: 617-623.

51. Pignon JP, le Maître A, Bourhis J; MACH-NC Collaborative Group. Meta-Analyses of Chemotherapy in Head and Neck Cancer (MACH-NC): an update. Int J Radiat Oncol Biol Phys 2007; 69 (2 Suppl): S112-S114.

52. Bonner JA, Harari PM, Giralt J, Cohen RB, Jones CU, Sur RK, et al. Radiotherapy plus cetuximab for locoregionally advanced head and neck cancer: 5-year survival data from a phase 3 randomised trial, and relation between cetuximabinduced rash and survival. Lancet Oncol 2010; 11: 21-28.

53. Sroussi HY, Epstein JB, Bensadoun RJ, Saunders DP, Lalla RV, Migliorati CA, et al. Common oral complications of head and neck cancer radiation therapy: mucositis, infections, saliva change, fibrosis, sensory dysfunctions, dental caries, periodontal disease, and osteoradionecrosis. Cancer Med 2017; 6: 2918-2931.
54. Vissink A, Jansma J, Spijkervet FK, Burlage FR, Coppes RP. Oral sequelae of head and neck radiotherapy. Crit Rev Oral Biol Med 2003; 14: 199-212.

55. Cox JD, Stetz J, Pajak TF. Toxicity criteria of the Radiation Therapy Oncology Group (RTOG) and the European Organization for Research and Treatment of Cancer (EORTC). Int J Radiat Oncol Biol Phys 1995; 31: 1341-1346.

56. Cooper JS, Pajak TF, Forastiere AA, Jacobs J, Campbell BH, Saxman SB, et al. Postoperative concurrent radiotherapy and chemotherapy for high-risk squamous-cell carcinoma of the head and neck. N Engl J Med 2004; 350: 1937-1944.

57. Trotti A, Bellm LA, Epstein JB, Frame D, Fuchs HJ, Gwede $\mathrm{CK}$, et al. Mucositis incidence, severity and associated outcomes in patients with head and neck cancer receiving radiotherapy with or without chemotherapy: a systematic literature review. Radiother Oncol 2003; 66: 253-262.

58. Rosenthal DI, Lewin JS, Eisbruch A. Prevention and treatment of dysphagia and aspiration after chemoradiation for head and neck cancer. J Clin Oncol 2006; 24: 2636-2643.

59. Duncan GG, Epstein JB, Tu D, Sayed SE, Bezjak A, Ottaway J, et al Quality of life, mucositis, and xerostomia from radiotherapy for head and neck cancers: a report from the NCIC CTG HN2 randomized trial of an antimicrobial lozenge to prevent mucositis. Head Neck 2005; 27: 421-428.

60. Lalla RV, Saunders DP, Peterson DE. Chemotherapy or radiation-induced oral mucositis. Dent Clin North Am 2014; 58: 341-349.

61. Elting LS, Cooksley CD, Chambers MS, Garden AS. Risk, outcomes, and costs of radiation-induced oral mucositis among patients with head-and-neck malignancies. Int J Radiat Oncol Biol Phys 2007; 68: 1110-1120.

62. Mekhail TM, Adelstein DJ, Rybicki LA, Larto MA, Saxton JP, Lavertu P. Enteral nutrition during the treatment of head and neck carcinoma: is a percutaneous endoscopic gastrostomy tube preferable to a nasogastric tube? Cancer 2001; 91: 1785-1790.

63. Denham JW, Peters LJ, Johansen J, Poulsen M, Lamb DS, Hindley A, et al. Do acute mucosal reactions lead to consequential late reactions in patients with head and neck cancer? Radiother Oncol 1999; 52: 157-164.

64. MacLellan J, Ali S, Curtis S, Baserman J, Dixon A. Analgesia for acute gingivostomatitis: a national survey of pediatric emergency physicians. CJEM 2017; 19: 32-38.

65. Trotti A. Toxicity in head and neck cancer: a review of trends and issues. Int J Radiat Oncol Biol Phys 2000; 47: 1-12.

66. Sciubba JJ, Goldenberg D. Oral complications of radiotherapy. Lancet Oncol 2006; 7: 175-183.

67. Beech N, Robinson S, Porceddu S, Batstone M. Dental management of patients irradiated for head and neck cancer. Aust Dent J 2014; 59: 20-28.

68. Porter SR, Fedele S, Habbab KM. Xerostomia in head and neck malignancy. Oral Oncol 2010; 46: 460-463.

69. Seikaly H, Jha N, McGaw T, Coulter L, Liu R, Oldring D. Submandibular gland transfer: a new method of preventing radiation-induced xerostomia. Laryngoscope 2001; 111: 347-352.

70. Jha N, Seikaly H, McGaw T, Coulter L. Submandibular salivary gland transfer prevents radiation-induced xerostomia. Int J Radiat Oncol Biol Phys 2000; 46: 7-11.

71. Sas R, Dawes C. The intra-oral distribution of unstimulated and chewing-gum-stimulated parotid saliva. Arch Oral Biol 1997; 42: 469-474. 
72. Sood AJ, Fox NF, O'Connell BP, Lovelace TL, Nguyen SA, Sharma AK, Hornig JD, Day TA. Salivary gland transfer to prevent radiation-induced xerostomia: a systematic review and meta-analysis. Oral Oncol 2014; 50: 77-83.

73. Kufta K, Forman M, Swisher-McClure S, Sollecito TP, Panchal N. Pre-Radiation dental considerations and management for head and neck cancer patients. Oral Oncol 2018; 76: 42-51.

74. Murdoch-Kinch CA, Zwetchkenbaum S. Dental management of the head and neck cancer patient treated with radiation therapy. J Mich Dent Assoc 2011; 93: 28-37.

75. Kielbassa AM, Hinkelbein W, Hellwig E, Meyer-Lückel H. Radiation-related damage to dentition. Lancet Oncol 2006; 7: 326-335.

76. Gorsky M, Epstein JB, Parry J, Epstein MS, Le ND, Silverman $S$ Jr. The efficacy of pilocarpine and bethanechol upon saliva production in cancer patients with hyposalivation following radiation therapy. Oral Surg Oral Med Oral Pathol Oral Radiol Endod 2004; 97: 190-195.

77. Momm F, Volegova-Neher NJ, Schulte-Mönting J, Guttenberger R. Different saliva substitutes for treatment of xerostomia following radiotherapy. A prospective crossover study. Strablenther Onkol 2005; 181: 231-236.

78. Nieuw Amerongen AV, Veerman EC. Current therapies for xerostomia and salivary gland hypofunction associated with cancer therapies. Support Care Cancer 2003; 11: 226-231.

79. Jeremic G, Venkatesan V, Hallock A, Scott D, Hammond A, Read N, Franklin J, Yoo J, Fung K. Trismus following treatment of head and neck cancer. J Otolaryngol Head Neck Surg 2011; 40: 323-329.

80. Goldstein M, Maxymiw WG, Cummings BJ, Wood RE. The effects of antitumor irradiation on mandibular opening and mobility: a prospective study of 58 patients. Oral Surg Oral Med Oral Pathol Oral Radiol Endod 1999; 88: 365-373.

81. Dijkstra PU, Huisman PM, Roodenburg JL. Criteria for trismus in head and neck oncology. Int J Oral Maxillofac Surg 2006; 35: 337-342.

82. Bensadoun RJ, Riesenbeck D, Lockhart PB, Elting LS, Spijkervet FK, Brennan MT, et al. A systematic review of trismus induced by cancer therapies in head and neck cancer patients. Support Care Cancer 2010; 18: 1033-1038.

83. Ichimura $K$, Tanaka $T$. Trismus in patients with malignant tumours in the head and neck. J Laryngol Otol 1993; 107 : 1017-10120.
84. Lee IJ, Koom WS, Lee CG, Kim YB, Yoo SW, Keum KC, Kim GE, Choi EC, Cha IH. Risk factors and dose-effect relationship for mandibular osteoradionecrosis in oral and oropharyngeal cancer patients. Int J Radiat Oncol Biol Phys. 2009; 75: 1084-1091.

85. O’Dell K, Sinha U. Osteoradionecrosis. Oral Maxillofac Surg Clin North Am 2011; 23: 455-464.

86. Ceponis P, Keilman C, Guerry C, Freiberger JJ. Hyperbaric oxygen therapy and osteonecrosis. Oral Dis 2017; 23: 141-151.

87. Ben-David MA, Diamante M, Radawski JD, Vineberg KA, Stroup C, Murdoch-Kinch CA, et al. Lack of osteoradionecrosis of the mandible after intensity-modulated radiotherapy for head and neck cancer: likely contributions of both dental care and improved dose distributions. Int J Radiat Oncol Biol Phys 2007; 68: 396-402.

88. Gomez DR, Estilo CL, Wolden SL, Zelefsky MJ, Kraus DH, Wong RJ, Shaha AR, Shah JP, Mechalakos JG, Lee NY. Correlation of osteoradionecrosis and dental events with dosimetric parameters in intensity-modulated radiation therapy for head-and-neck cancer. Int J Radiat Oncol Biol Phys 2011; 81: e207-e213.

89. Jacobson AS, Buchbinder D, Hu K, Urken ML. Paradigm shifts in the management of osteoradionecrosis of the mandible. Oral Oncol 2010; 46: 795-801.

90. Bras J, de Jonge HK, van Merkesteyn JP. Osteoradionecrosis of the mandible: pathogenesis. Am J Otolaryngol 1990; 11: 244-250.

91. Tahir AR, Westhuyzen J, Dass J, Collins MK, Webb R, Hewitt S, Fon P, McKay M. Hyperbaric oxygen therapy for chronic radiation-induced tissue injuries: Australasia's largest study. Asia Pac J Clin Oncol 2015; 11: 68-77.

92. Marx RE. Osteoradionecrosis: a new concept of its pathophysiology. J Oral Maxillofac Surg 1983; 41: 283-288.

93. Hampson NB, Holm JR, Wreford-Brown CE, Feldmeier J. Prospective assessment of outcomes in 411 patients treated with hyperbaric oxygen for chronic radiation tissue injury. Cancer 2012; 118: 3860-3868.

94. Mansfield MJ, Sanders DW, Heimbach RD, Marx RE. Hyperbaric oxygen as an adjunct in the treatment of osteoradionecrosis of the mandible. J Oral Surg 1981; 39: 585-589. 